\title{
Defining the situation in Revelation: John's intention and action-lines ${ }^{1}$
}

\author{
H Theunissen (Newcastle) \\ Research Associate: Department of New Testament Studies \\ University of Pretoria
}

\begin{abstract}
This article argues that the purpose of Revelation is to strengthen the group identity of the church and not to encourage a persecuted church. This view is proposed by a symbolic-interactionistic analysis of Revelation. Symbolic interaction focuses on the construction of situations through symbols, the interaction between symbols and the grouping of symbols. Through the analysis and the corresponding action lines certain conclusions pertaining to the problems in the church and the author's intention (the writing being a reflection of his mind process) are possible. The overall problem seems to be the fading boundaries of identity between the church and society. John's intention is to bring about the necessary alterations. He thus exhorts the church through warnings, calls to repent and even threats. This is achiebed by defining the situation to the church through symbolic scenes.
\end{abstract}

\section{INTRODUCTION}

Revelation has been the object of a mainly historical approach for many centuries (Barr 1986:403). This approach legated a fixed reconstructed historical frame of reference: Persecution! According to this "traditional scenario" the churches were oppressed (Klauck 1992:153; Smith 1995:356). Consequently and part of this legacy, the purpose of Revelation was to encourage the seven churches. Stanley (1993:291), in his evaluation of the commentaries on Revelation by Boring, Fiorenza, Mulholland and Wall, attests to the prevalence of this viewpoint when he remarks, "... these authors posit a situation of persecution, actual or expected, as the occasion which motivated John to pen Revelation."

The last decade of the previous century produced voices objecting to the

\footnotetext{
${ }^{1}$ This article is based on a doctoral thesis written in Afrikaans, under the supervision of Prof Dr J G van der Watt. The title of the dissertation can be translated as Defining the situation in the Revelation of John: A symbolic-interactionistic analysis of the text. The approach, argumentation and conclusions followed in the article were substantiated in the thesis.
} 
traditional scenario. ${ }^{2}$ The matter concerning the frame of reference and the purpose of Revelation are under dispute. In the quest for clarity, it is applicable to remember that new answers are not always the result of more data, rather of new questions, theories and presuppositions (Gager 1982:260). In line with this philosophy, a social-scientific venture has been undertaken by the writer to assist in this quest. It has been argued that the purpose of Revelation is related to the intention of its author in the sense that intention provides the frame of reference for understanding Revelation (Theunissen 1997:19-20). Symbolic-interaction, a social-psychological perspective was utilized to search for intention. The concept of "definition of the situation"3 proved useful as an analytical perspective (Theunissen 1997:20-21).

I am well aware that intention of an author is a contentious and debatable issue. One must remember though that the definition of person (being) or the definition of what constitutes a person changed over the centuries. Personhood is nowadays understood as a social or even rhetorical construct (Vorster 2000:107, 112). To my mind, the John of Revelation is a rhetorical construct and so is the intention presented by the rhetorical construct, called Revelation.

\section{EXPLANATORY REMARKS ON SITUATION-DEFINITION}

The basic premise of Situation-definition is that people have a symbolic capacity that serves as an interpretative mechanism between physiological and sociological stimuli. People do not act in terms of an objective reality, but in terms of their interpretation of the objects they encounter in reality. This premise and the perspective as such can be explicated by pointing out some of the root ideas on which it is based (Theunissen 1997:37-38).

- Interaction is a situational phenomenon. Interaction never occurs without a constructed Situation. ${ }^{4}$ The construction of a Situation would imply the following phases, if the motion were slowed down. The Self,

\footnotetext{
${ }^{2}$ Cf Barr (1986:405-408), Botha (1988:87-102), Thompson (1990), Klauck (1992:154-155), Murphy (1994:187) and Smith (1995:358). Objections against historical criticism as such are also immanent and boosted by the post-modern wave of thinking (Botha et al 1998:4-6).

3 "Definition of the situation" is derived from W I Thomas who explained: "Preliminary to any self-determined act of behaviour there is always a stage of examination and deliberation which we may call the definition of the situation" (Lauer \& Handel 1983:127). Henceforth, referred to as Situation-definition.

4 "Situation" is a technical term and can be defined as an intersection between time and space consisting of symbols that is constructed by an actor who is in the process of interaction. A Situation is thus a holistic space and will be written with a capital letter whenever used in this technical sense.
} 
that is the actor who constructs the Situation, ${ }^{5}$ enters an intersection between space and time. The Self then indicates all objects (concrete, social or abstract) that are applicable according to him/her in this intersection and attaches meaning to them. Objects and their attached meanings, function as symbols. The indicated symbols are simultaneously clustered around master-symbols, which usually consist of actors. The Self thus constructs or defines the Situation by means of symbols in order to make sense of the encounter and to determine a line(s) of action. Action-lines are therefore determined by interpretation and not by an objective assessment of an objective situation.

- $\quad$ The symbolic value of objects could be derived from a referencegroup, ${ }^{6}$ or from the interaction-process itself. The symbolic capacity of the Self makes it possible for the Self to attach a meaning to objects that concurs or differs from the meaning the reference-group would attach.

- $\quad$ The Self is consequently forced to present its Situation-definition in such a way that the group or audience will accept the interpretation and follow the suggested action-lines. Defining the Situation is mainly a problem-solving activity during which the Self and interaction with symbols play the major part.

- Exploring Revelation through the lenses of Situation-definition meant two things.

- Firstly, an integrated methodological technique was used. The questions that Situation-definition wants to ask the text, as well as the manner in which it wants to ask it, has been reconciled with a semantic reading (questioning) of the text. The postulates and concepts with which Situation-definition operate, have been synergised with a structural and semantic reading in order to accommodate the nature of a Biblical text (Theunissen 1997:67-72, 104-123).

\footnotetext{
${ }^{5}$ The Self is a technical term in social psychology and refers basically to the reflexive capability of an actor, the possibility to look at oneself as an object amongst others. The Self represents the central working of any actor in interaction. In any Situation the Self thus represents the position of the central actor, the one who enters in interaction and constructs the symbolic Situation (Theunissen 1997:40-47).

${ }^{6}$ A Reference-group refers to the group where an actor belongs and with whom s/he shares values and norms (Theunissen 1997:43-46). A Reference-group consists of one or more Significant Other's (an individual exercising influence upon the Self in terms of norms and values) and a Generalized Other (a social-psychological technical term referring to the totality of individuals that is important for the functioning of the Self).
} 
- Secondly, the Situation-definition process had to be reversed. The text does not take us through the process of defining the Situation, but represents the defined Situation, as well as the correlating action-lines. Analytically speaking, the different Situations indicated by the text were first demarcated. Four macro-Situations were demarcated (Theunissen 1997:125-147), namely A (1:1-8), B (1:9-3:22), C (4:1-22:5) and D (22:6-21). The analysis indicates that $B$ represents a concrete Situation while $C$ represents a generalized Situation. $B$ has been analysed in depth and the conclusions were paradigmatically tested in C and D. Following the demarcation phase, the Situations were analysed by marking the objects that are indicated, determining the symbolic values of the indicated objects and attending to the clustering of these symbols around master-symbols (mostly actors). The Self, one of the indicated objects, was identified as John. He is the actor in Revelation who is reflexive and speaks of himself in an objective manner. John also represents the position of the central actor in the book. It is through his eyes that we see. He relates his perceptions to other parties. John also represents the position of the author of Revelation, whoever s/he or they may have been (Theunissen 1997:20). Lastly, the interaction in the demarcated situations was analysed. The actors (social objects) who are in interaction, as well as the nature and reason for interaction were investigated. Situation-definitions were then proposed and tested against the action-lines by asking the question whether the action-lines and Situation-definitions correlate. Lastly, conclusions were made concerning the problem that the Self is trying to solve and thus the intention of the author.

What follows is a concise report on the analysis of B (1:9-3:22). B comprises of eight smaller Situations. B1 (1:9-20) represents an introductory Situation. B2-8 (2:1-3:22) represents the letters to the seven churches. Situation B has been explored by an in-depth exegesis in the fashion mentioned above. Only information applicable for our discussion is being shared.

\section{SITUATION B (1:9-3:22): SITUATION-DEFINITION.}

\subsection{Explicit interaction}

The following diagram displays in a summarized fashion the result of the analysis of Situations B2-8 as far as master-symbols and the nature of explicit interaction between these symbols are concerned. In terms of our topic, nature of interaction refers to the action-lines that are being prescribed and whether the interaction is of an encouraging or exhortatory nature. For the 
sake of space, action-lines are indicated in terms of exhortation or encouragement. Exhortation represents action-lines presupposing problems in the church and the resultant condemnation, threats or warnings.

Encouragement represents a positive action-line that condones conduct or a certain state of affairs as acceptable.

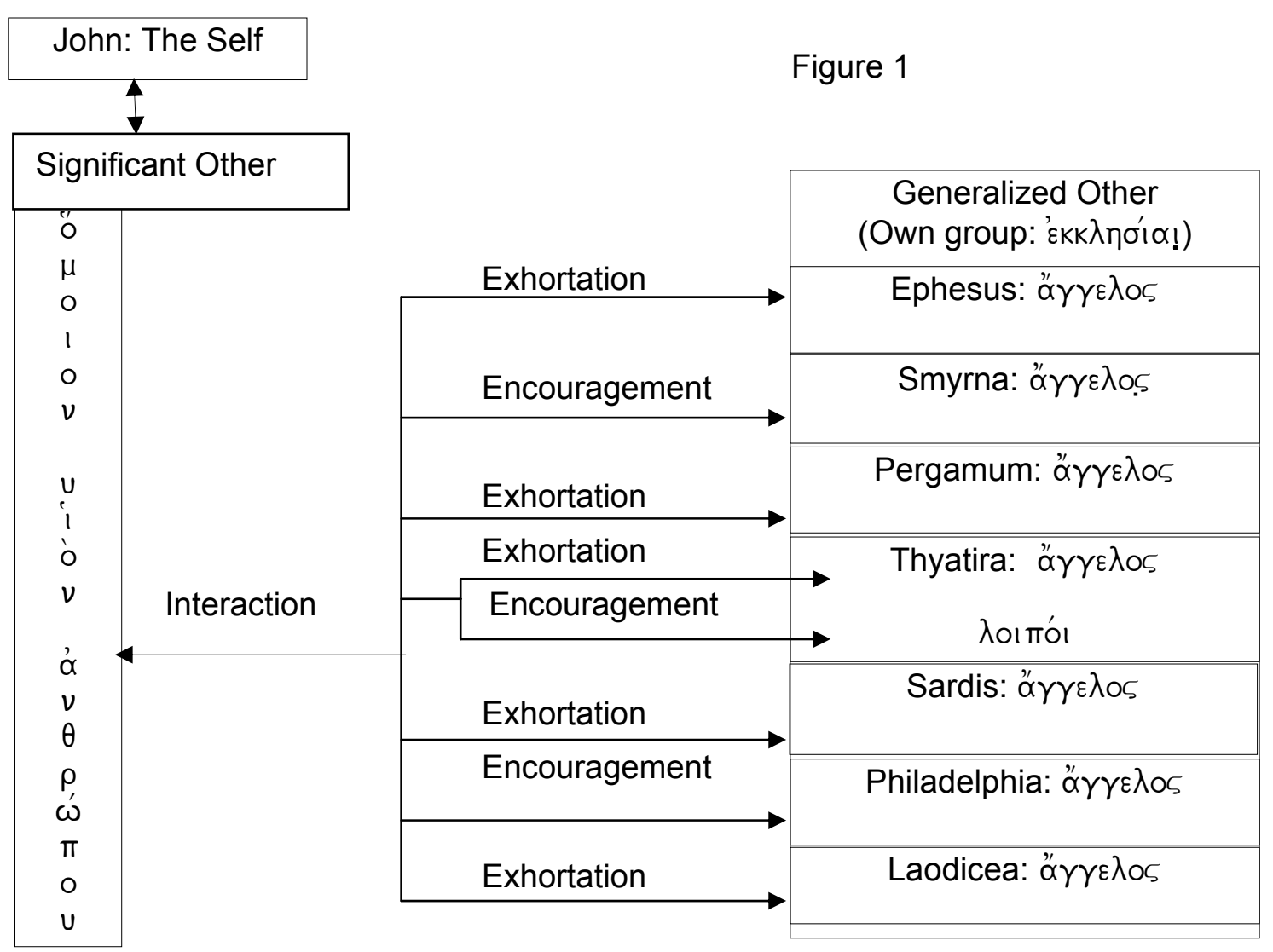

\subsection{Implicit interaction}

The following diagram displays in a summarized fashion the result of the analysis of Situations B2-8 as far as implicit interaction is concerned. The text implies that interaction happened between parties within a particular church, or between the churches and parties outside the church environment. 
Figure 2

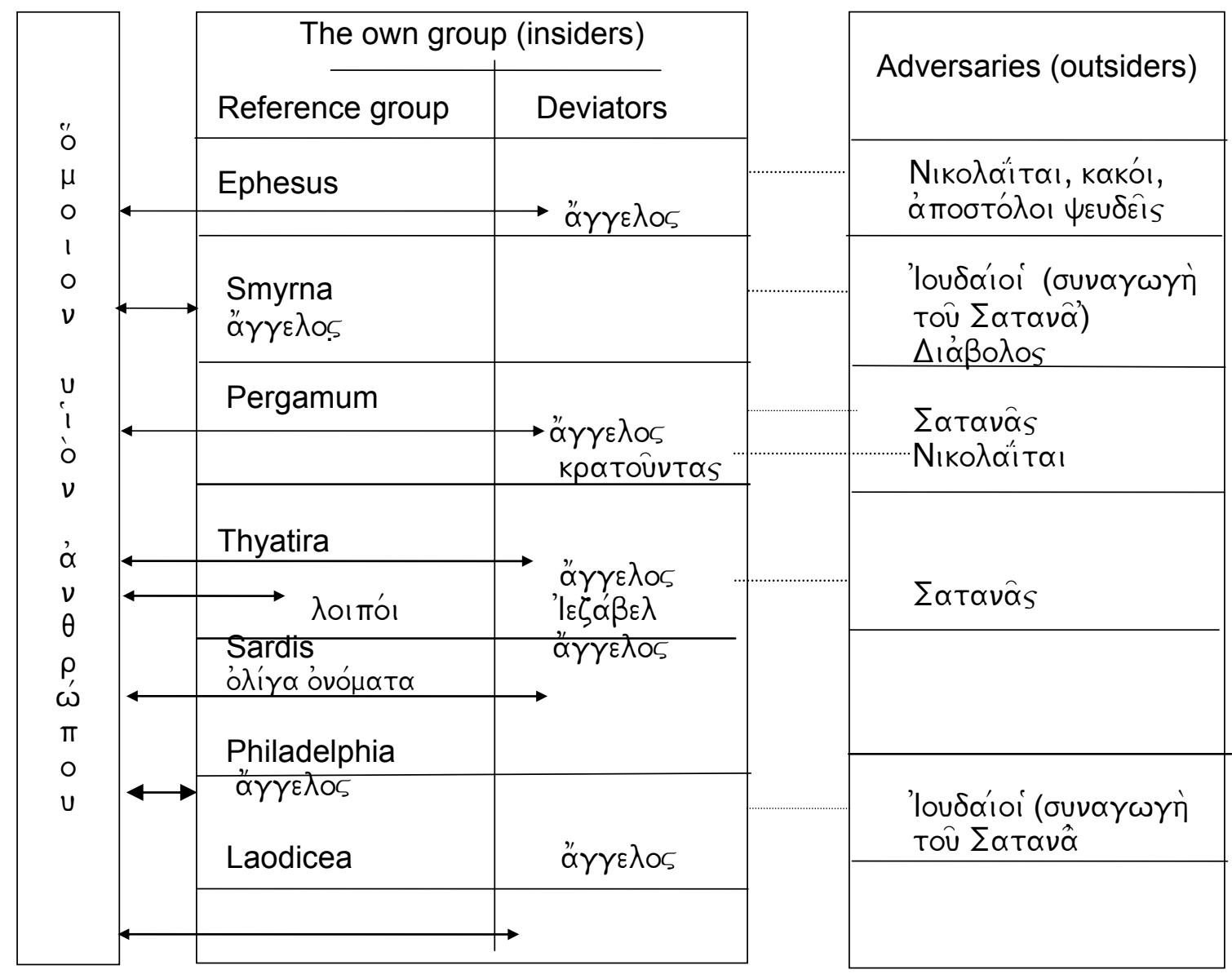

The Situation-definition of Situation B shows the following important issues:

- Actors. The introductory Situation B1 (1:9-20) indicates four actors that play an important role in Situations B2-8 (2:1-3:22). The most

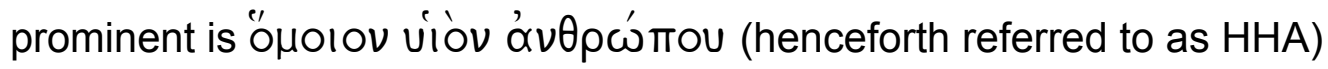
who interacts with John. The interaction concerns the assignment of John. John must write his observations down and send this writing to seven churches. In situations B2-8, the contents to the individual churches are described.

The description of situations B2-8 shows two important phenomena. The $\alpha^{\prime \prime} \gamma \gamma \varepsilon \lambda \circ$ of a particular church, not the church, is being addressed directly. Indirectly though, the church is being addressed. The use of the genitive construction makes it is obvious that the church and its ${ }^{\prime} \gamma \gamma \varepsilon \lambda$ os represents one group, namely the own group.

Secondly, HHA interacts directly with each ${ }^{\prime \prime} \gamma \gamma \varepsilon \lambda$ os. John is not really in play according to the text. He does not interact with the churches, but acts as a scribe. Viewed from a symbolic-interactionistic perspective 
though, John does interact with the churches, but through HHA. The Self enters the Situations in the respective churches through the Significant Other. ${ }^{7}$

- Interaction. The interaction in Situations B2-8 (Figure 1) happens exclusively between the Significant Other ( $\mathrm{HHA}$ ) and the own group. HHA does not interact with any adversaries. ${ }^{8} \mathrm{He}$ deals exclusively with

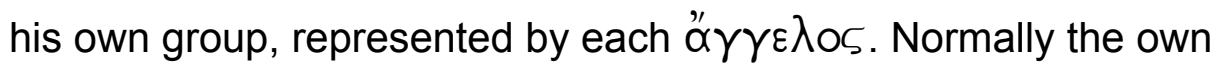
group would also be the reference group. In other words, they are expected to represent the norms and values of the Self, as is the case with Smyrna and Philadelphia. In some instances however, the own group as a whole deviates from the applicable norms and values (cf Ephesus, Pergamum and Laodicea). A distinction within the own group must then be made between reference and deviatory groups. In other cases, a group within the own group maintains the norms and values and acts as reference group (cf Thyatira and Sardis).

- The reasons for interaction. The interaction in situations B2-8 is caused by three categories of problems. In the case of Ephesus, Sardis and Laodicea the interaction concerns the problem of relationship with HHA. In the case of Pergamum and Thyatira, it concerns the problem of heresy, as well as the accommodation of heretics in the church. In both instances, the heresy is related to the matter of idolatry and immorality. In the case of Smyrna and Philadelphia, the interaction concerns the problem of anticipated tribulation.

- The description of each church situation indicates in an explicit and implicit manner, four role-players as cause of the said problems. The church itself causes the problem of relationship (Ephesus, Sardis and Laodicea). Thus, the own group is a role-player in its problem.

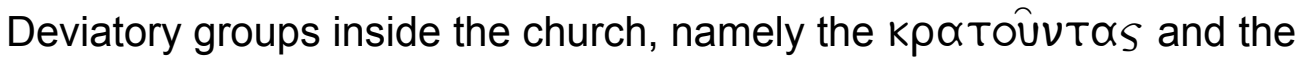
Jezebel-group, cause the heretical problems (Pergamum and Thyatira). These deviatory groups are connected to the Nicolaitans. They share the same ethics (2:14-16). The problem of suffering (Smyrna and Philadelphia) is caused by the 'loudo'iol. It is meaningful that the role-

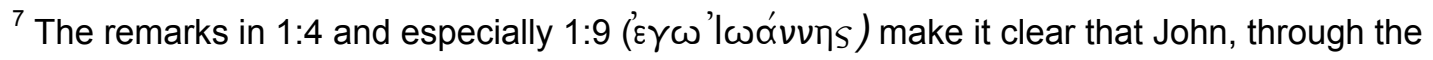
medium (1:1-2), is the actor (the Self) who actively interacts with the churches. For the purpose of self-presentation, positioning and legitimisation, John employs his Significant Other (who, by the way is also a Significant Other of the churches).

${ }^{8}$ Adversaries represent actors or parties that are situated outside or over and against the own group (the church).
} 
players in the last two instances are linked with Satan. They function as part of the Satan-party. They act as agents of Satan.

- The intention of John is related to his Situation-definition. To John's mind there are specific problems in the churches. He addresses these issues by sketching the Situations in such a way that the problems will become clear to his target-group and in order that the target-group will accept the prescribed lines of action. The Situation-definitions and the corresponding action-lines, thus reflect on his intention.

- The relational and heretical problems are matched with action-lines of an exhorting, threatening and condemnatory nature. The action-lines in the cases of anticipated suffering are encouraging. The exposition of 1:9-3:22 shows all these issues to have one thing in common, namely the problem of identity. In this regard, two arguments should suffice for the moment.

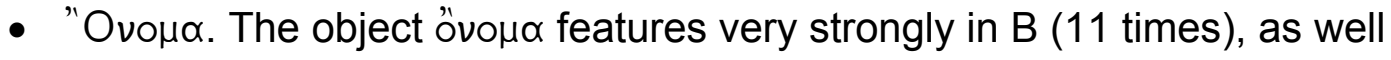
as the remainder of Revelation (37 times in total). It is one of the favourite words according to Beckwith (1979:223). "Ovoux is symbolic of identity. "Ovoux identifies actors in terms of what they stand for and where they are positioned in a Situation. Complementing this argument is the more or less 25 different proper names that occur numerously in 1:9-3:22. All the proper names are linked with certain conduct and certain groups. Identity and the identification of actors are a real important issue in these chapters. ${ }^{9}$

- Groups. Through his Situation-definitions and action-lines, John clearly distinguishes between insiders and outsiders. The distinction between the two groups is made in terms of the ruling of HHA. The ruling of HHA is based on conduct that complies with what he and his Father approves of. ${ }^{10 "}$ "E $\rho \gamma \alpha$ plays a major roll in defining the nature of relationships with Christ. This is a major motif in 1:9-3:22. The identity of the church is derived from Christ, the relationship with him, his teaching and the responding conduct, as well as the manner in which one handles suffering.

\footnotetext{
${ }^{9}$ De Villiers (2000:65-82) elaborates on this issue and substantiates the point of view.

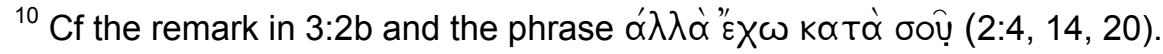


The line between insiders and outsiders gets obscure if the boundaries of a group are not well defined. Ultimately the group loses its identity. The mentioned problems, as well as the emphasis on identity, groups, norms and values, are symptoms of this overall identity problem. John's intention is to bring the necessary alterations about and to restore the true, the "Christ-like" identity of the church.

\section{SITUATIONS C (4:1-22:5) AND D (22:6-21): EXPLORING RELATIONSHIP, HERESY AND ANTICIPATED SUFFERING AS INDICATION OF THE OVERALL GROUP- IDENTITY PROBLEM}

The objective of the paradigmatic test was to see if the generalized Situation (C) and the epilogue (D) support the findings in the concrete Situation (B). ${ }^{11}$ Firstly, enquiries were made whether the same problems and role-players feature in the remaining text. Secondly, enquiries were made concerning the nature of action-lines in the remaining text. Thirdly, the correlation between problems and action-lines was determined.

\subsection{Relational problems}

To detect relational problems in the text is a complicated matter. Motives, thoughts and attitudes are not easily evaluated. Several factors in situation $B$ made it possible to define relational problems. Firstly, HHA himself, who has the ability to search and see the inner being, was the speaker (2:23).

Relational issues could be pointed out to Ephesus and Sardis, in spite of all the visible good works that seem to indicate a live and sound relationship. Secondly, HHA has been the speaker in concrete situations. Based on concrete conduct $\mathrm{He}$ could point out to Laodicea that there is a relational problem. Situation $C$ though, constitutes a global and generalized situation. No local church is in play. In line with this shift, the role of HHA changes from church-visitor in concrete Situations to transcendental role-player in God's council. The change in symbolic value supports this shift. The symbol $H H A$ is now changed to Lion and Lamb with horns (5:5-6), as well as Word of God (19:13), depending on His role. In this part of the text, the relationship with the churches is difficult to analyse. In spite of this, the following could be noted.

\footnotetext{
${ }^{11}$ The relationship between 1:9-3:22 and 4:1-22:5 has to do with a concrete and a generalized situation, not with seven introductions and a main part (contrary to Bauckham 1993:13-14).
} 
Worship features prominently in situation C and D Beckwith (1979:223) points out that $\Pi \rho \circ \sigma K \cup v \varepsilon \dot{\varepsilon} \omega$ is one of the favourite words being used in Revelation (24 times) and evenly distributed throughout the book. In various ways, the church as a whole is called upon to worship God alone and to give honor to Him. ${ }^{12}$ This call emphasizes the importance of an exclusive relationship with God. The intimate, personal and undisturbed relationship anticipated in 21:122:5 surely supports the importance of this matter. The covenant relationship, expressed in the familiar Father-son formula, also supports the matter of exclusive worship (21:7). In a negative way, the warning that people who do not have a relationship with God, or whose relationship became inclusive of other gods and deviatory conduct, will be excluded from communion with God, appears twice in $C(21: 8,27)$ as well as in $D(22: 14-15)$.

The phenomenon of generalization also strengthens the case. From 4:1 onwards it is explicit that only two groups or sides are in play, namely the side of God and the side of Satan. Relational issues are very important in determining these sides. God's side consists of people who have been cleansed by the blood of the Lamb (4:9) and conquered by means of the same blood (12:11). They have the name of God and the Lamb on their foreheads and they follow the Lamb $(14: 1,4)$. They worship God exclusively and their names have been written in the book of life, that is the book of the slain Lamb $(13: 8 ; 17: 8)$. On the other side we have the followers and worshippers of the Dragon and the Beast $(13: 4,8)$. They also carry a mark, that of the Beast (13:17). The events expressed by these descriptions imply personal and exclusive relationships.

\subsection{Heretical problems: Immorality and Idolatry}

\subsubsection{Analyses of the appearance of immorality as a problem}

In B the focus was on the matter of immorality, as well as the relation with the heresy of the Nicolaitans in concrete church situations. ${ }^{13}$ In 2:22 immorality is described as adultery and Jezebel features as the main figure in this regard. ${ }^{14}$

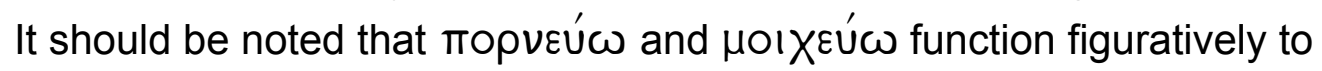
indicate inappropriate relationships. It does not necessarily refer to physical sex, but to heretical groups and thus wrong ethics and conduct. The actionlines are exhortative and threatening, as expected. In Situation C and D this

\footnotetext{
${ }^{12}$ Meyer (1997) points out that the function of hymns in Revelation is to call for worship.

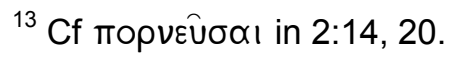

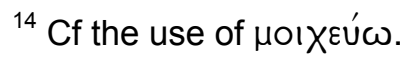




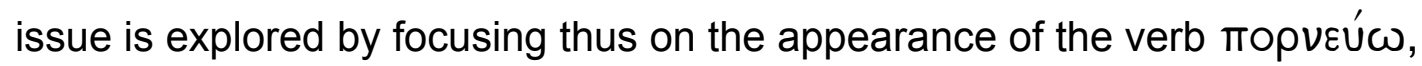
as well as the derived nouns mópvos and порveía.

\section{- Situation C}

In 9:21 there is a reference to immorality, but in the broader context of lawlessness. ${ }^{15}$ The people involved are indicated as the other people (9:20). Immorality is not explicated and John seems to be labeling, namely that immorality is typical of the group who worships Satan. The action-line is condemnatory and situated in a context of plagues, judgment and calls for repentance (9:20-21). This statement is confirmed by the remarks in $9: 4$ and 14:1-5 in connection with the other category of people, the people of God. It is typical of this group not to defile themselves with women, but to remain pure $(14: 4)$ and to tell the truth (14:5).

Immorality is personified as a woman in chapters 17-18 (17:1). She has a name on her forehead: Great Babylon, mother of the immoral people (17:5). She exercises power over the kings of the earth (17:18). She is supported by the Beast (17:3) and exists in the midst of humanity (17:15). The devils and demons find shelter with her (18:2). The immoral woman also personifies wealth, luxury and glittering, the essence of her existence (18:14). Here as well, immorality obtains the broader meaning of a worldly lawlessness (17:6), lust (18:7), unjustness (18:5) and wealth (18:3). Immorality thus, does not only refer to sexual immorality. It rather describes the inherent character or spirit of this woman. She seduces humanity and destroys the earth through her spirit of unethical conduct. The immoral relationship between the kings and the woman is a figure of speech $(18: 3,9)$. They share in the immoral spirit she offers. The relationship of the business people and the ship-captains to the woman is not described as immoral. Their conduct though, compares with that of the kings. They use her wealth to enrich themselves $(18: 3,15,17,19)$.

\section{- Situation $D$}

The remark in 22:15 falls in the same category as the remark in 9:21 that has been discussed.

\footnotetext{
${ }^{15}$ Here, as in 21:8, Topveí, murder, witchcraft and theft are all mentioned in one.
} 


\subsubsection{Remarks concerning the problem of immorality}

It is not important for our discussion whether immorality was an objective reality in societal life, or whether Rome was the promoter of a culture of immoral conduct. Our interest lies with the Situation-definition. John's perception of the Situation is very clear. The authorities, as well as the people of the Roman Empire had nothing to do with God and His ways. They lived contrary to the will of God and did evil things. ${ }^{16}$ They did not obey God's commandments. ${ }^{17}$ They kept themselves busy with immorality, murder, theft, witchcraft and lies. This happened on such a scale that John had to generalize in terms of two groups of people. According to John, all people living contrary to God's will and who let themselves be deceived by a worldly attitude, form part of the Satan's group. The Immoral Woman, the mother of all immoral people, personifies or symbolizes this group. The forceful, blatant and extensive painting of this symbol emphasizes that immorality (lawlessness) takes a prominent place in the Situation-definition of John. Immorality is an essential problem and danger for the church. It takes priority over the problem of persecution in the Book of Revelation. Therefore the description of the judgment in chapters 17-20 concentrates on the issue of immorality in terms of " $\varepsilon \rho \gamma \alpha(20: 13)$. Whenever the persecutors, the Dragon and the Beast, are the topic of discussion in this regard, the issue is their deception of humanity $(19: 20 ; 20: 3,8)$. The persecution of the church is not mentioned, except in the context of the activities of the immoral woman. ${ }^{18}$ She caused the spiritual death of believers (17:6).

To label immorality as the activity of a specific category of people who bear the spirit of the Woman, shows that the problem at hand is not only a moral one, but also one of identity. The anti-symbol in this regard is the women in chapter 12. Her children obey the commandments of God and keep the witness of Jesus (12:17). The church thus, must distance itself from the immoral Woman and her group to protect its identity. The real issue here is groups, group-identity and group-boundaries. Based on this Situationdefinition, John prescribes the action-line (18:4): My people go out from her in order that you do not take part in her sins. This action-line is important. Firstly, it implies that the people of God are not outside or out of danger. They are

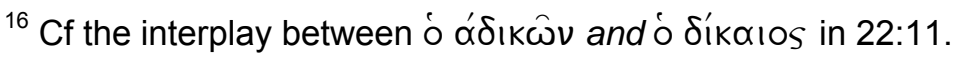

${ }^{17}$ Cf '́vто入 $\alpha_{S}$ in 12:17.

${ }^{18}$ Klauck (1992:175) points out that those texts in Revelation referring to the killing of believers, especially those in chapters 17-20, are to be seen against the background of the strong "Literarisierung der Stoffe". The context of texts like 17:6 and 18:24 is thus important. The focus in 17-18 is on the immoral woman. The killing of believers refers symbolically to apostasy and syncretism caused by deception.
} 
called upon to move out. Now, surely the issue is not to obtain geographical distance, but distance in terms of norms and conduct, thus a symbolic distance. Furthermore, the action-line is of a warning or exhortative nature.

The issue of immorality is prevalent throughout Revelation and two complete chapters are put aside for this issue. Immorality was a real problem as far as John was concerned.

\subsubsection{Analysis of the matter concerning idolatry}

Idolatry is indicated by John as on the same level of importance as the problem of immorality. In Situation B the focus was on the eating of sacrificial meat by Christians who were deceived in this regard. ${ }^{19}$ John compares this situation with the events described in Numbers 22-24. This association of events makes it clear that to John's mind the eating of sacrificial meat is the same as idolatry. Eating sacrificial meat is symbolic of idolatry. It has also been noted earlier that the idolatry issue is related to groups that are connected with the Satan.

\section{- Situation C}

In 9:20 idolatry is mentioned. It is described as worshipping of devils and handmade gods. In chapter 13 , idolatry is linked with the beast and the Dragon. Idolatry happens by worshipping an image of the beast $(13: 15)$ or the beast itself (13:8), or the Dragon (13:4). People are forced to worship (13:16), even killed if they refuse to worship (13:15). People are also deceived and tempted to worship (13:3-4,14). John of course refers to a contemporary phenomenon, the so-called imperial cult. The remarks in 9:20 imply that John views idolatry in a much more extensive way.

The previous remarks show that idolatry and worship are related. Idolatry to John's mind is the phenomenon that people do not worship God and do not give honor to God (16:8). Therefore, it is important that John does not fall at the feet of the angel to worship him. Only God may be worshipped (19:10). As in the case of immorality, John generalizes and typifies idolatry as belonging to the sphere of a certain group. The people belonging to the Satan, they are described as idolaters $(19: 20 ; 20: 4)$.

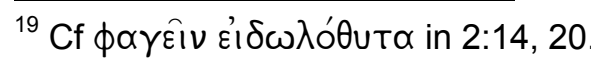


- Situation D

The idea that only God must be worshipped and no one else, not even angels, is stressed in 22:8-9. It is also emphasized that idolaters will not enter the New Jerusalem (22:15).

\subsubsection{Remarks concerning the problem of idolatry}

The perception of John is important for our purposes. The discussion shows clearly that idolatry figures prominently in the Situation-definition. Again, there is a powerful and explicit sketch of two beasts, symbolizing the problem of idolatry and the threat for the church, but also the issue of identity. The antisymbol is the evenly impressive symbolic scene of the throne of God (4:1-11), the beings around the throne, and the events occurring as result of the throne. In both chapters 4 and 13, worship is a central theme. The scale, on which idolatry is practiced, emphasizes the prominence of the problem. In this regard John mentions the whole world (13:3), every tribe, people, tongue and nation (13:7), as well as all the inhabitants of the earth (13:8). They worship or shall worship the Dragon and the Beast. He speaks in terms of a global phenomenon or Situation. Lastly, the prominence of this problem is also emphasized by the judgment in chapters 19-20, which focuses on the Beasts and the Dragon.

Throughout Revelation the church is thus called upon to worship God, ${ }^{20}$ to endure in this worship and to remain faithful (13:9-10; 19:10b; 22:9). In other words, the church must not partake in idolatry but maintain the identity of God's group.

\section{- Summary}

It is important that John defines the group of Satan in terms of idolatry and immorality $(9: 20-21 ; 14: 8-9 ; 16: 9,11 ; 21: 8 ; 22: 15)$. He adds only one other label to this group, that of heretics (22:15). In Situation B heresy, idolatry and immorality are birds of the same feather. This label is thus expected in the remaining part of the writing. The discussion of immorality and idolatry verifies this connection in a different way as well. Both phenomena happen primarily by means of deception. The immoral Woman deceives regarding immorality and the Beast from the earth (false prophet) deceives in terms of idolatry. It is clear that the problem of heresy in relation to immorality and idolatry figures through the whole of Revelation as a problem that is addressed by John.

\footnotetext{
${ }^{20} \mathrm{Cf}$ the description in $4: 8-11 ; 5: 9-14 ; 7: 9-12 ; 15: 3-4 ; 19: 4-5$. The right conduct for the believer is modulated, so to speak.
} 


\subsection{Persecution and suffering}

The book of Revelation breathes a spirit of persecution and suffering. The frame of reference for understanding Revelation is consequently seen in terms of a situation where the church was persecuted. The persecutors could be the Roman Empire, the synagogue or even society at large. The result is of cause suffering. It is true that John indicates numerous objects to this effect. For the sake of clarity though, a distinction must be made between all these references.

\subsubsection{The hour of trial}

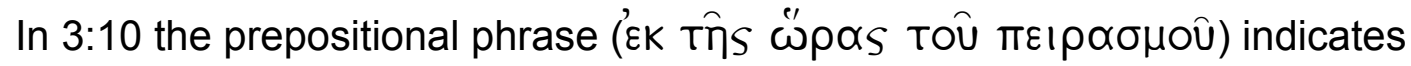
an object that symbolizes a time of positioning (Theunissen 1997:413-415). God is the subject of this event involving the whole world in order that the inhabitants of the earth may be trialed and positioned in relation with God. The events in 6:1-16:21 explicate and elaborate on this hour of trial. These events are related to the wrath of $\operatorname{God}(6: 16 ; 15: 1,7)$ and try to effect repentance $(9: 20 ; 16: 1-21)$. These testing events also apply to the believers, but the assurance is given that they will remain standing (6:17-7:17). There is progression in this trial and from 9:4 onwards the target-group is exclusively the people of the beast. ${ }^{21}$ The important point is that the hour of trial has nothing to do with the persecution of the church.

\subsubsection{The final judgment}

The main description of the final judgment is found in 17:3-20:15. ${ }^{22}$ This description contributes to the spirit of suffering in the Book, but must obviously be left out of this matter. Again, God is the subject of this event. The judgment has nothing to do with persecution of the church.

\subsubsection{The persecution of the church}

General appearances. Oppression or persecution of the church is being generalized in Revelation. Believers in general and for all times are being persecuted because they believe in Christ. In this regard the ' $\varepsilon v$ 'Inoou phrase in 1:9 sets the tone of the Book. It indicates that suffering and persecution are part of the church's existence because of the relationship with Christ. ${ }^{23}$ This

\footnotetext{
${ }^{21}$ The negative effect of the seven trumpets and the seven bowls concerns the non-believers, not the church.

${ }^{22}$ Proleptic elements of the judgment appear in chapters 6-16.

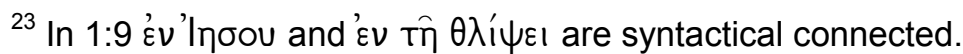


way of thinking is supported by other statements in Revelation. ${ }^{24}$ John's tendency to generalize in terms of two groups thus also applies to persecution.

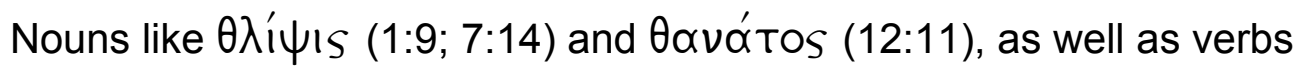

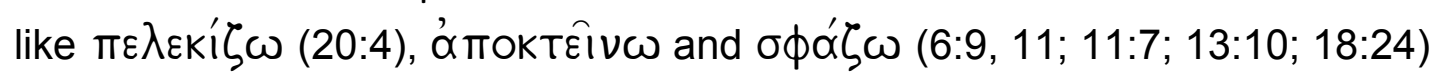
point to the persecution of believers. In 16:6 (17:6) this matter is pointed out by means of a description of bloodshed. The agents in this tale of persecution change. Sometimes it is the Dragon (12:11), sometimes the Beast (11:7; 13:9, $10,15 ; 20: 4)$, or the inhabitants of the earth $(6: 9 ; 16: 6 ; 17: 6 ; 18: 24 ; 19: 2)$ and sometimes there is no indication $(1: 9 ; 7: 14)$. What is clear though, is that the agents could only be from the Satan's group.

The question remains whether the persecution of the church is to be taken up literally or symbolically. ${ }^{25}$ The question also remains whether reference is made to concrete situations or to anticipated situations. According to Reddish, ${ }^{26}$ John works with a perception of persecution and applies a martyr-Christology or martyr-symbol to show the church what it really means to be a Christian. The church must be loyal to Christ without any compromise. Not even death must threaten this loyalty.

I agree that John operates by means of perceptions. It is doubted though, that this perception has mainly to do with suffering (persecution) and that this remains the frame for understanding Revelation. The Situationdefinitions show that the dominant action-lines are exhortative and not encouraging. At least two other matters have been pointed out as important in Revelation. John may be implementing a martyr-symbol. The intention of this motif though, would be different. The church is called upon not to compromise their "Christ-like" identity with the faith and practices of society.

\section{- Concrete uses}

The reference to the death of Antipas (2:13) refers to a concrete event. This though, happened in the past and does not reflect on the

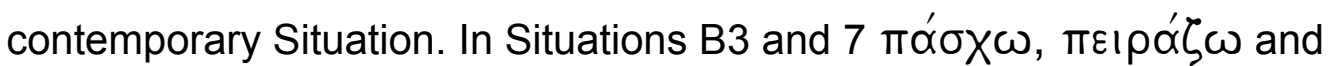

\footnotetext{
${ }^{24}$ Cf $6: 9-11 ; 12: 11,17 ; 13: 9,10 ; 16: 6 ; 17: 6 ; 18: 24 ; 20: 4$.

${ }^{25} \mathrm{Cf}$ the remarks in note 18.

${ }^{26}$ Reddish (1988:85-95) argues that circumstances led John to the perception that a time of persecution and suffering for the church is immanent. It does not matter if persecution is present. He creates the impression that a time of crisis is at hand. He then applies a martyrChristology to encourage the church to remain steadfast (1988:90). According to Reddish the martyr-idea is the primary motif in the writing (1988:86). The writing intends to construct an alternative symbolic universe, because the old order (God is in control) collapsed. The dragon and its forces are dominant. The readers needed a different understanding of their reality (1988:92).
} 
$\theta \lambda i \psi$ is points to anticipated suffering. The only possible concrete and contemporary references to persecution, is found in chapter 13 . The historical canvas for this symbolic painting is maybe the prevalent political and societal practices. In such a case, the Satan is the cause of suffering and he uses the beasts of Rome (imperial cult) as agents. The political set-up and government thus are the persecutors. They act on behalf of Satan and try to involve people in this worship through threats of capital punishment, imprisonment and deportations. One could of course also reason for an anticipated Situation. John is reflecting on what is about to happen according to 4:1-2. Chapter 13 could also be an anticipated Situation.

If John operates with a martyr-motif that he applies differently in different Situations, it would be wise to distinguish between a martyr-theology and martyr-Situation. The one is a rhetorical vehicle and the other a frame of understanding. Statements, communicating that the Jews who are not Jews and all the inhabitants of the earth are oppressors, support the motif-idea. The whole world, in terms of the theology, constitutes a situation of persecution for the church because the Satan is behind everything and he does not favor the church (12:17). The transcendental frame of chapters 12 and 13 strengthens the motif option by employing a spiritual war concept. Terminology like

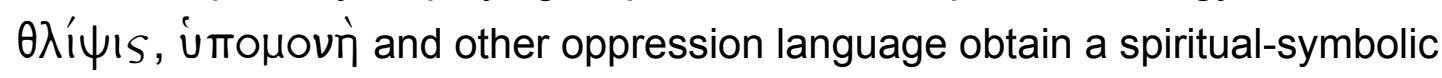
meaning.

Textually speaking, there is no solid ground to postulate a concrete persecution of the church as the problem that is being addressed by the Book. The applicable texts could be interpreted in various ways. Based on the information in chapters 2-3, the balance of probabilities lies with the matter of anticipated suffering. The visions gave John a view of events that will happen in time. This anticipated suffering would pose certain problems to the church. John's intention in this regard is to encourage the church to keep its identity, even through times of suffering. God looks after them. Who God is, what God is capable of, what God has already done and what God is about to do, must give the church security and assurance for what lies ahead. All role-players and time-factors are in God's hands. ${ }^{27}$ The church must endure and remain steadfast.

\footnotetext{
${ }^{27}$ Revelation gives this assurance, starting with the vision of the throne (4:1-11) and concluding with the vision of the New Jerusalem, free from the Dragon, beasts, ungodliness, sin and suffering.
} 


\section{CONCLUDING REMARKS}

It seems that John operates with the same Situation-definition in Situations $C$ and D (4:1-22:21) as in Situation B (1:9-3:22). According to John's perception, heresy (immorality and idolatry) and anticipated suffering are the main problems facing the church of his day. To his mind, the exclusivity of the relationship with Christ has been compromised. The action-lines correlate with the proposed problems.

Though the definition of problems remains the same throughout, there is development in Situation $\mathrm{C}$ and $\mathrm{D}$ as far as role-players are concerned. The interaction remains between Christ and the church, but John plays a more prominent role. John does not act through his Significant Other anymore, but through his Self. He himself interacts with the church. He relates what he sees and hears. John's Significant Other also fulfils a different role with a different symbolic value, as has been pointed out. The church-angels do not function anymore and the church is basically present as a spectator. The adversaries (Satan and his agents), God and God's Son features more prominently and their conduct and interaction is anticipated, evaluated and described more extensively.

Thus, the problem-Situations and action-lines do not change throughout the writing. In Situations $C$ and $D$ the problems are rather made more clear and put in the right (serious) perspective by taking away the curtains of time and space. The church is allowed to see behind the scenes, how Satan operates, the effect these operations have on the world and church, as well as the scale of these operations. The curtains being drawn back require the change in role-players, as well as the spectator role of the church. The overhead problem should be clear to the observing church: Group-identity! Who is who and who belongs where? Where are we (the church) positioned? Group-boundaries and maintaining them through certain conduct, norms and values strengthen identity. Identity from its side will support clarity on group-boundaries. This is the overall problem addressed by Revelation, the disintegration of group-boundaries.

\subsection{The traditional frame of understanding: Persecution}

The Situation-definitions and action-lines based on the textual analyses show that the traditional scenario is too exclusive and has no real stand as the main frame of understanding. Revelation, according to its text, does not battle with the problem of persecution and a suffering church. The main battle is with the Christ-like identity of the church in the world, which is lacking. Heresy (immorality and idolatry), as well as compromising the relationship with Christ, are the main components of the identity problem. The intention of John is not to encourage the church. His intention is to alter and restore the identity of the church. The danger and the problems that he defines in this regard lead him 
to exhort and warn, to call for repentance and even to threaten. In some instances the Christ-like identity exists, but will lead to intensified suffering. In such instances, John's intention is to strengthen this identity and this leads him to encourage. I would thus agree that Revelation still relates to the broader definition of crisis or establishment literature, as long as we include the matter of identity. ${ }^{28}$

Though the purpose of this paper (and the mentioned dissertation) was not to reflect on historical contexts, it is pointed out that more recent ideas on the imperial cult have merit and would support the proposed intention. It seems that the imperial cult was not in essence a matter of worship Caesar or die. The imperial cult provided a religious coherency that incorporated social and economical life. The matter of guilds and societies, ${ }^{29}$ economical progress and religion were all blended and as such posed existential dilemmas for Christians ${ }^{30}$ It was easy to be deceived into compromising norms and values, especially when prophetic voices inside the church promoted this line of thought. Once heretical ideas have been accepted, syncretism happened spontaneously and not by force. Group-identity and group-boundaries faded and were trespassed because norms and values were unclear.

\subsection{Experimenting with Symbolic-interaction (SI)}

$\mathrm{SI}$ forces the exegete to trace the meanings with which the text functions. It assists in noticing symbols, the interaction between symbols, the symbolic construction of Situations and the correlation with action-lines. In this sense SI could be a useful perspective to explore the rhetorical intention behind a text, insofar as the text reflects the minding or rhetorical process of its author(s).

SI creates awareness that texts are not static and thus invites the reader to become part of the interaction process in an educated way. This involvement would of course include the matter of intertextuality, which was not part of this study.

SI also points to the phenomenon that the problem on which a writing concentrate, does not have to correlate with what is problematic according to reconstructed historical contexts. Interpretation and perceptions play an important role. Historians could deduct from sources that Rome practiced good government, for argument sake. This deduction does not matter. What matters, is what John's perception of Rome was. Historians could be

\footnotetext{
${ }^{28}$ Cf the discussion by Decock (1999:5-9).

${ }^{29}$ Cf Klauck (1992:167-170).

${ }^{30}$ Cf Kraybill (1996:24-101) on the blending of imperial cult and commerce, the upward mobility structures (commerce and military service), and the acceptance of syncretism by the majority of Christians.
} 
convinced that the church was being persecuted. This does not count. What the problem of the church was according to the perception of John, that is the telling perspective.

\section{Works consulted}

Barr, D L 1984. The Apocalypse as a symbolic transformation of the world: A literary analysis. Interpretation 33(1), 39-50.

Barr, D L 1986. Elephants and holograms: From metaphor to methodology in the study of John's Apocalypse. SBL (Seminar Papers), 400-411. Chico, CA: Scholars Press.

Bauckham, R 1993. The theology of the Book of Revelation. Cambridge: Cambridge University Press.

Beckwith, I T 1979. The Apocalypse of John. Grand Rapids, MI: Baker Book House.

Botha, $\mathrm{J}$ et al 1998. A South African response to The postmodern Bible - A time to break down or a time to build up? Neotestamentica 32(1), 1-35.

Botha, P J J 1988. God, emperor worship and society: Contemporary experiences and the book of Revelation. Neotestamentica 22(1), 87-102.

Decock, P B 1999. Some issues in apocalyptic in the exegetical literature of the last ten years. Neotestamentica 33(1), 1-33.

De Villiers, P G R 2000. Prime evil and its many faces in the Book of Revelation. Neotestamentica 34(1), 57-85.

Gager, J G 1982. Shall we marry our enemies? Sociology and the New Testament. Interpretation 36, 256-265.

Garrow, A J P 1997. Revelation. London: Routledge.

Klauck, H-J 1992. Das Sendschreiben nach Pergamon und der Kaiserkult in der Johannesofferbarung. Biblica 73(2), 153-182.

Kraybill, J N 1996. Imperial cult and commerce in John's Apocalypse. Sheffield: Sheffield Academic Press. (JSNT, Suppl 132).

Lauer, R H \& Handel, W H 1983. The theory and application of symbolic interactionism. Englewood Cliffs, NY: Prentice Hall.

Meyer, E 1997. ' $n$ Godsleer van Openbaring soos vervat in die himnes. Skrif en Kerk 18(2), 305-322.

Murphy, F J 1994. The book of Revelation. Currents in Research: Biblical Studies 2, 181-225.

Reddish, M G 1988. Martyr Christology in the Apocalypse. JSNT 33, 85-95.

Smith, R H 1995. Why John wrote the Apocalypse (Rev 1:9). Currents in Theology and Mission 22(5), 356-361.

Stanley, J E 1993. Some words on the Bible's last word: An assessment of four recent commentaries on Revelation. Christian Scholars Review 22(3), 291296.

Theunissen, H 1997. Situasie-definisie en die Openbaring aan Johannes: 'n Simbolies-interaksionistiese teksanalise. DD-Proefskrif, Universiteit van Pretoria.

Theunissen, H 1999. Vermaan of bemoedig Johannes die kerke? Skrif en Kerk 20(1), 187-206.

Thompson, L L 1990. The Book of Revelation: Apocalypse and empire. Oxford: Oxford University Press.

Vorster, J N 2000. (E)mpersonating the bodies of early Christianity, Neotestamentica $34(1), 103-124$. 